\title{
A case report of QT prolongation with glycopyrronium bromide in a patient with chronic tamoxifen use
}

\author{
Michael H. Chiu', Nawaf S. Al-Majed ${ }^{2}$, Ryan Stubbins ${ }^{3}$, Dylan Pollmann ${ }^{4}$ and Roopinder K. Sandhu²*
}

\begin{abstract}
Background: Glycopyrronium bromide has recently been approved as a once daily maintenance inhalation therapy for moderate to severe chronic obstructive pulmonary disease (COPD). Efficacy and safety trial data have found rare cases of significant QT prolongation. To our knowledge, we describe the first case report of QT prolongation $>600 \mathrm{~ms}$ with initiation of glycopyrronium bromide in a real world setting.
\end{abstract}

Case presentation: A 78-year-old female with moderate COPD recently started on glycopyrronium bromide, presented to Emergency Department (ED) with syncope. Her past medical history was significant for a left total mastectomy and she had been on Tamoxifen for 9 months. One day prior to her presentation, she had visited a naturopathic clinic for a vitamin infusion resulting in emesis. The following day she continued to feel dizzy and had a witnessed syncopal episode without any reported cardiac or neurological symptoms preceding the event or after regaining consciousness. In the emergency department, she reported dizziness and was found to be hypotensive. Her symptoms completely resolved with intravenous fluids. Lab work was normal however her electrocardiogram (ECG) demonstrated a QTc interval of 603 and 631 ms (Friderica and Bazett's respectively) with a normal QT interval on her baseline ECG prior to initiating Tamoxifen. She was admitted to the Cardiology service for further work-up of QT prolongation. Her syncope was felt to be due to orthostatic hypotension and the QT prolongation secondary to medications, which were both discontinued during her admission. After 2 days, her QT interval normalized consistent with the half-life of Glycopyrronium bromide (13-57 h) compared to Tamoxifen (8-14 days).

Conclusion: Glycopyrronium bromide is guideline recommended as first line therapy for prevention of exacerbation in moderate to severe COPD however safety data had been limited to select populations. This case report highlights the need for future studies to identify high-risk populations at potential risk of life-threatening arrhythmias who may benefit from periodic ECG surveillance.

Keywords: Chronic obstructive pulmonary disease, QT prolongation, Glycopyrronium bromide (Seebri), NVA237

\section{Background}

Chronic obstructive pulmonary disease (COPD) is a common condition, comprising of a spectrum of emphysema, bronchitis and bronchiolitis that involves parenchymal destruction and infiltration [1]. Pharmacologic maintenance therapy for COPD involves bronchodilation via $\beta-2$ adrenergic agonist, corticosteroids, anticholinergics and long acting muscarinic antagonists (LAMA) [2].

\footnotetext{
*Correspondence: rsandhu2@ualberta.ca

2 Division of Cardiology, University of Alberta, Edmonton, AB, Canada

Full list of author information is available at the end of the article
}

Glycopyrronium bromide (GB) is a recently approved synthetic competitive muscarinic antagonist that acts at the bronchial smooth muscle and inhibits acetylcholinemediated bronchoconstriction. GB is recommended as first line therapy for preventing exacerbations in moderate to severe COPD [3].

Efficacy and safety trial data in selected populations have found variable results regarding QT prolonging effects with GB therapy and rare cases of QT prolongation $>500 \mathrm{~ms}$ [4-9]. A small, randomized controlled study found no repolarization abnormalities with a single 
supra-therapeutic dosing of GB in young, healthy adults [10]. After extensive investigation and consideration of other possible offending medication, we report here the first case of severe and transient QT prolongation consistent with pharmacokinetics of GB in the real-world setting.

\section{Case presentation}

A 78-year-old female with a past medical history significant for breast cancer and moderate COPD presented to Emergency Department with syncope. Nine months prior to admission, she underwent left total mastectomy for invasive ductal carcinoma and was started on Tamoxifen $20 \mathrm{mg}$ daily. Home medications included GB $50 \mathrm{mcg}$ once daily, Salbutamol, calcium and a multi-vitamin. GB was started 3 months prior to her presentation for syncope.

The day prior to admission, she received an IV vitamin infusion consisting of a mixture of thiamine, folic acid, multivitamin and magnesium sulfate at a naturopath clinic. Shortly after completion of the IV infusion, she developed emesis and took 2 tablets of dimenhydrinate. The following day, she reported dizziness as she walked across the kitchen and passed out after sitting in a chair. The patient reported no palpitations, chest discomfort, nausea, warm sensation or diaphoresis prior to the syncope event. She was not witnessed to have any seizure like activity and when she regained consciousness, reported immediate awareness of surroundings with no neurological deficits, no tongue biting, bowel or urinary incontinence. There was no previous history of syncope and no family history of sudden cardiac death. Her initial blood pressure in the ambulance was $70 / 50 \mathrm{~mm} \mathrm{Hg}$. Hemodynamics normalized after administration of intravenous fluid and her symptoms resolved. Oxygen saturation was above $97 \%$ and telemetry revealed normal sinus rhythm with a heart rate of 77. Precordial examination was unremarkable with regular normal heart sounds and no murmurs. In the Emergency Department, blood tests including complete blood count $(\mathrm{CBC})$, serum electrolytes (potassium, calcium, magnesium), glucose, creatinine and thyroid stimulating hormone were normal. Electrocardiogram (ECG) showed a corrected QT interval using Fridericia (QTcF) and Bazett's formula (QTcB) of 603 and $631 \mathrm{~ms}$ respectively (Fig. 1) and she was admitted to the cardiology service for further investigation of the etiology for her QT prolongation.

Prior to starting Tamoxifen her QTcF and QTcB were 439 and 440 ms respectively (Fig. 2), however no ECG was obtained after initiation of Tamoxifen and prior to starting GB. Her last dose of Tamoxifen and GB were the day of admission with both medications discontinued at presentation.

An echocardiogram revealed that her left ventricular ejection fraction was $>60 \%$ with no valvular or regional wall motion abnormalities. Serial electrocardiograms demonstrated corrected QTcF and QTcB respectively of

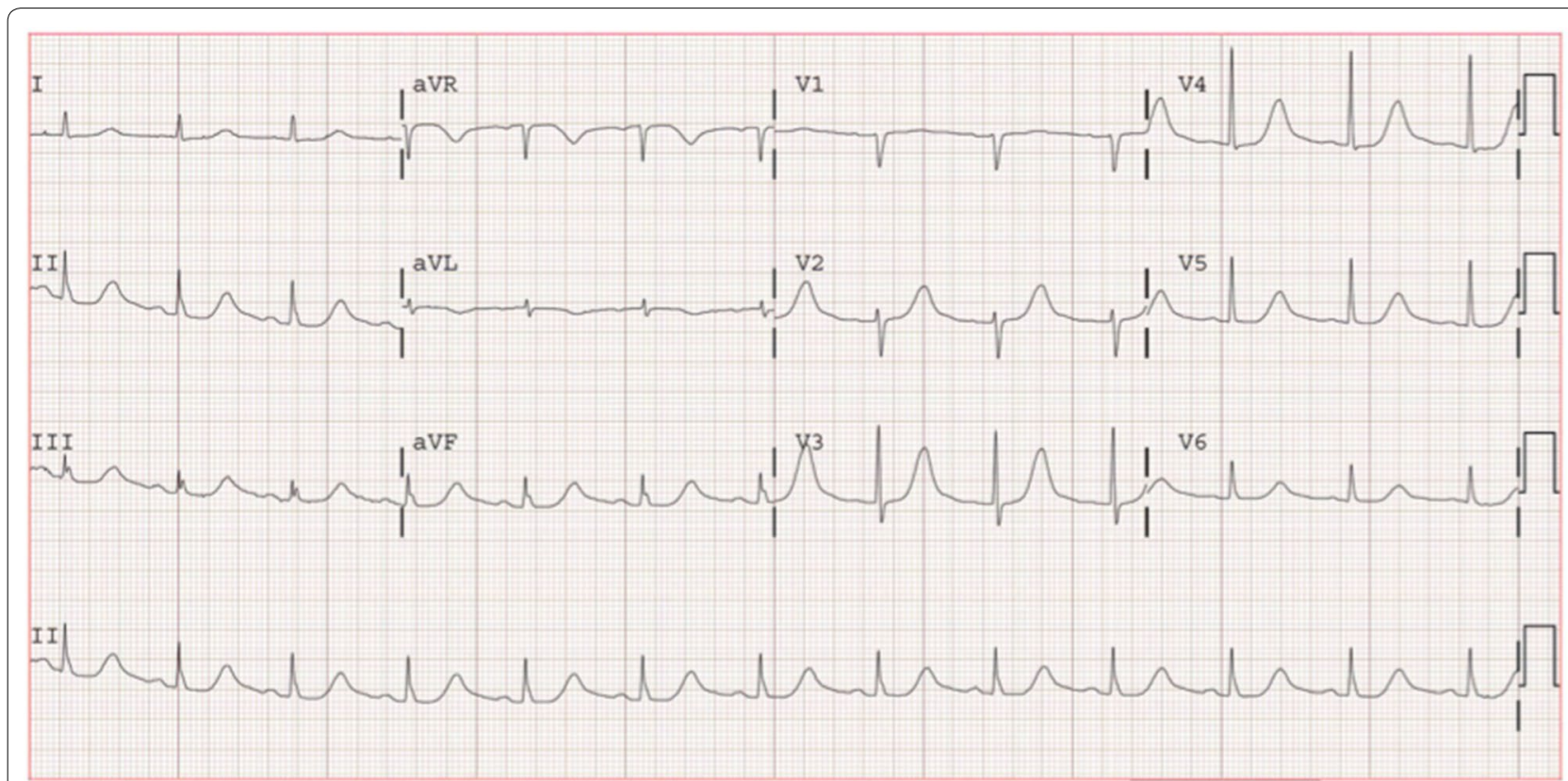

Fig. 1 Electrocardiogram at hospital presentation demonstrating prolonged corrected QT intervals of 603 ms using Fridericia's equation and 631 ms using Bazett's formula 


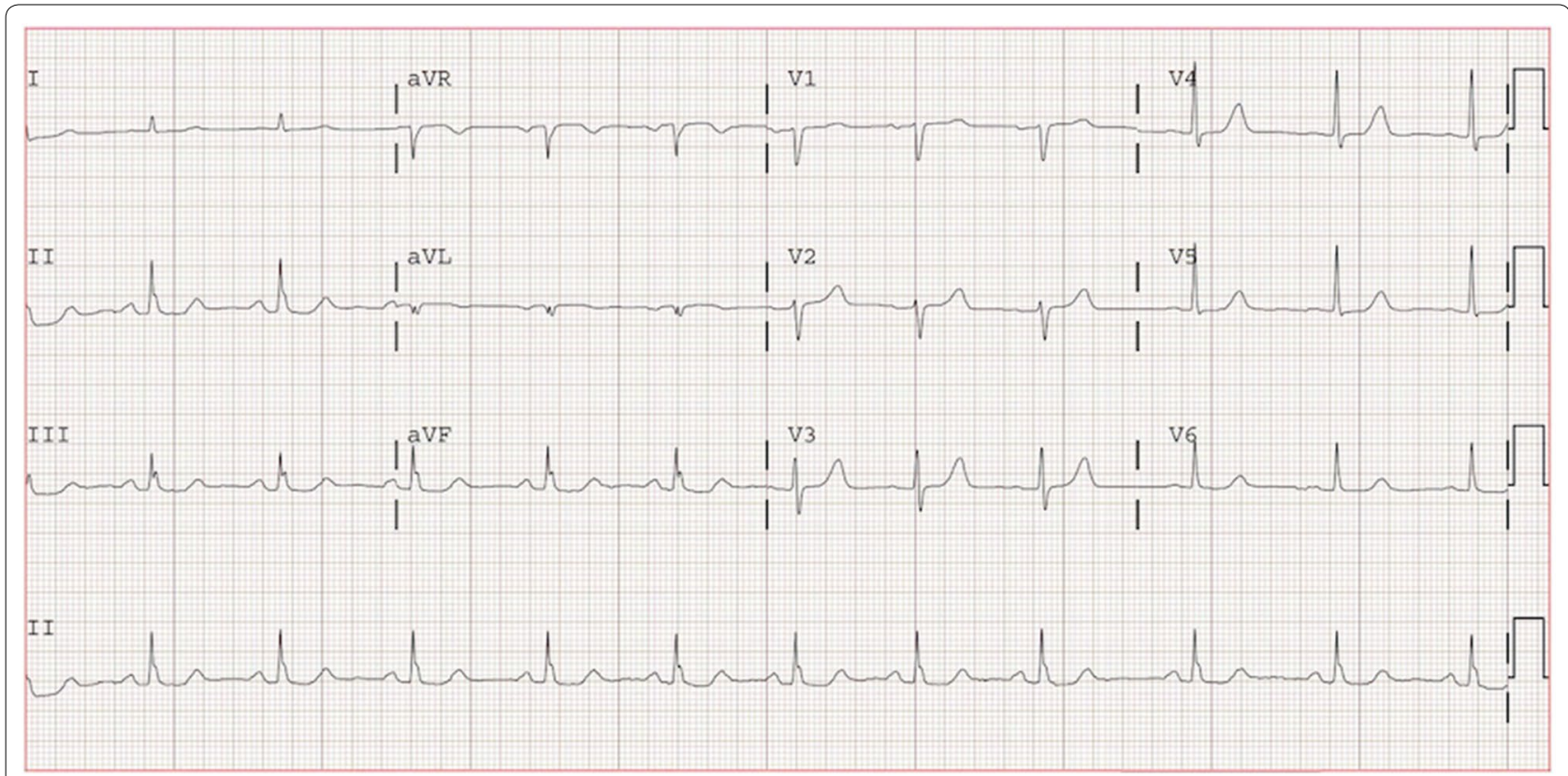

Fig. 2 Electrocardiogram prior to starting Tamoxifen with corrected QT intervals of 439 ms using Fridericia's equation and 440 ms using Bazett's formula

603 and $631 \mathrm{~ms}$ day 0, 496 and $514 \mathrm{~ms}$ day 1 , and 446 and $455 \mathrm{~ms}$ on day 2 and 442 and $460 \mathrm{~ms}$ on day 3 (Fig. 3). There were no arrhythmias seen on telemetry. Syncope was felt to be secondary to orthostatic changes and she was discharged on day 3 after admission.

\section{Discussion}

The QT interval represents the time interval between the onset of the QRS complex and the end of the T wave including ventricular depolarization and repolarization. There are many factors that can induce QT prolongation including left

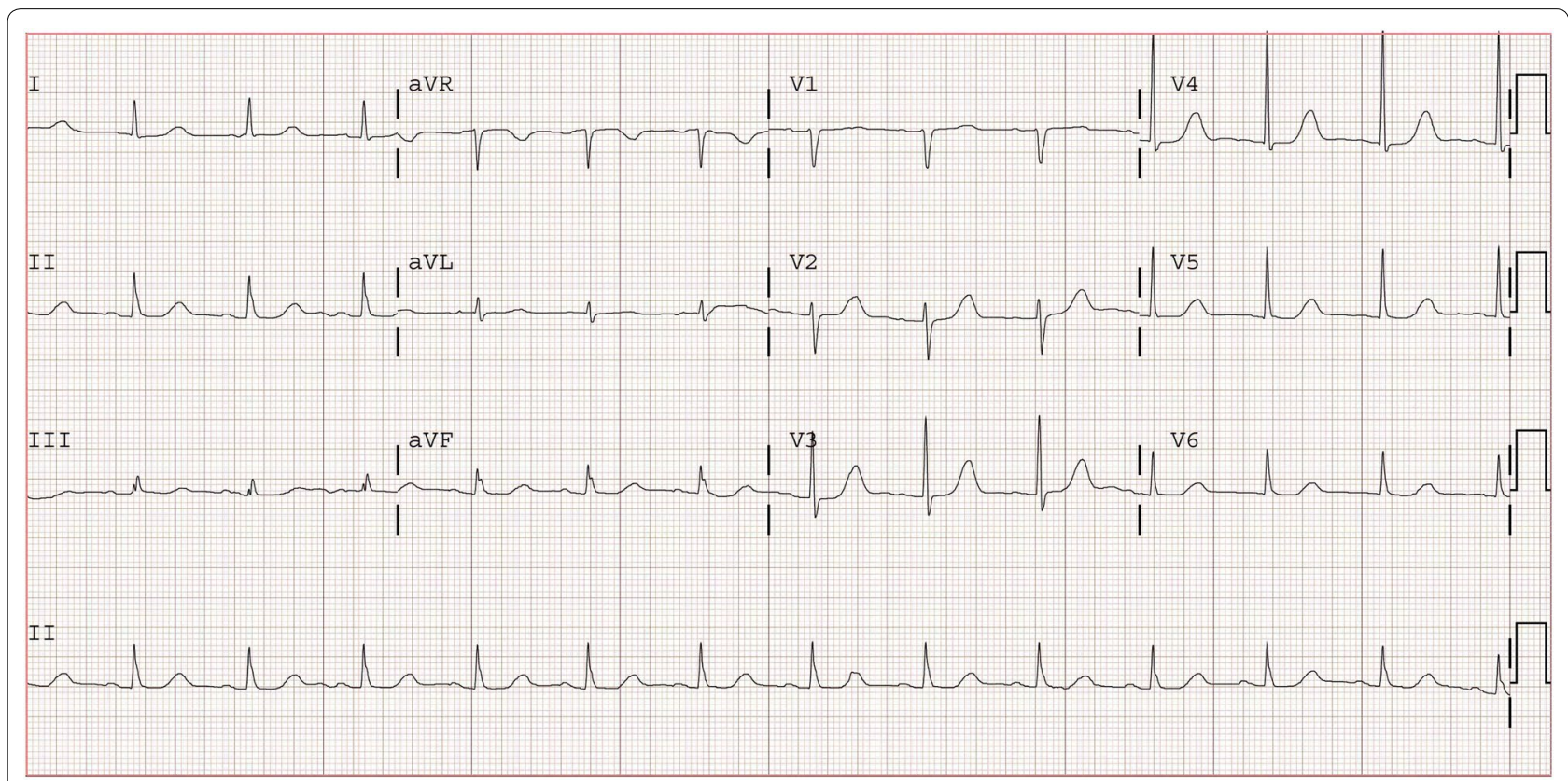

Fig. 3 Electrocardiogram $72 \mathrm{~h}$ after stopping glycopyrronium with corrected QT intervals of $442 \mathrm{~ms}$ using Fridericia's equation and $460 \mathrm{~ms}$ using Bazett's formula 
ventricular hypertrophy, heart failure, myocardial ischemia, hypertension, diabetes, thyroid dysfunction, bradycardia and electrolyte abnormalities including hypokalemia and hypomagnesaemia. Congenital long QT syndrome (LQTS) is due to direct mutations in specific genes such as the cardiac delayed rectifier potassium channel (KCNQ1 and $\mathrm{KCNH} 2$ ) or the cardiac sodium channel (SCN5A). In congenital LQTS, exercise, emotional or physical stress is presumed to be an underlying trigger for long QT events. Aside from congenital LQTS, there is a $30 \%$ heritability of the QT interval in the general population [11].

Medications represent one of the largest causes of prolonged QT [12]. The primary mechanism of drug induced QT prolongation is blockade of the rapid component of the delayed rectifier potassium channel leading to prolonged action potential duration [13]. Drugs that inhibit the human ether-à-go-go-related gene (hERG) K+ channel have the highest risk of QT prolongation. HERG inhibition increasing susceptibility to early after depolarization that can result in torsades de pointes (TdP) and a risk of sudden cardiac death $[11,12,14]$.

In our case, the possible offending drugs responsible for QT prolongation were GB and Tamoxifen. The pharmacokinetics of the two drugs differs considerably; the half-life of GB is $13-57 \mathrm{~h}$ while that of Tamoxifen is 4-9 days with a single dose. Clinical studies of QT prolongation associated with Tamoxifen reported normalization of the QT interval within 8-14 days after drug cessation $[15,16]$. There are no known drug interactions between the anticholinergic properties of GB and estrogen receptor properties of Tamoxifen and both have different excretion pathways [17]. The mechanism of action for GB is via Muscarinic M1 and M3 receptor blockade, which prevents parasympathetic mediated bronchoconstriction [18]. GB has less selectivity toward the M2 receptor present in the heart, pacemaker cells and conduction system [18].

In experimental studies, the effects on the hERG $\mathrm{K}^{+}$ channel blockade channels have previously been examined during product safety development. In-vitro patch clamp experiments reported a progressive dose dependent inhibition of hERG current [19]. Inhibition of the
hERG current was $0.6 \%$ for the vehicle and 13.2, 18.3 and $30.6 \%$ for $3.2,31.8$ and $95.5 \mu \mathrm{g} / \mathrm{mL}$ of GB respectively. Novartis product normogram mentions an IC50 value of $>300 \mu \mathrm{M}$, which is greater than 500,000 times of the maximal recommended concentration $C_{\max }[19$, 20]. Electrophysiological rabbit studies reported no proarrhythmic activity at supertherapeutic dosing. Furthermore, telelmetry studies on beagle dogs with supertherapeutic IV GB (12> $\mathrm{C}_{\max }$ in humans) reporting a transient QTc shortening of up to $30 \mathrm{~s}$ observed for up to $2 \mathrm{~h}[20]$.

In clinical studies, the safety and efficacy of GB have been studied in six randomized controlled studies (GLycopyrronium bromide in COPD airWays-GLOW) [4-9]. The safety profile testing for GB in the GLOW trials excluded patients with a QTc greater than $450 \mathrm{~ms}$ in males and $470 \mathrm{~ms}$ in females. Other exclusion criteria included moderate or severe renal dysfunction, prior lung cancer, active infection, urinary retention or history of alpha 1 anti-trypsin. A history of breast cancer was not specifically reported as an exclusion criterion. Three of these trials reported slightly variable results ranging from no significant incidence to low incidence of QT prolongation in GB compared to placebo or active comparator, and rare reports of QT prolongation $>500 \mathrm{~ms}$ (Table 1) [4-9]. In the GLOW trials no significant QT prolongation was noted between GB versus placebo. The variable QT results in the GLOW trials prompted a randomized, partially blind, placebo and positive (moxifloxacin) control, 3 way cross-over study among 73 healthy adults [10]. Compared to placebo, no significant QT prolonging effect was observed after inhalation of a single supratherapeutic $(400 \mu \mathrm{g})$ dose of GB.

\section{Conclusion}

Glycopyrronium bromide is guideline recommended as first line therapy for prevention of exacerbation in moderate to severe COPD however safety data particularly in regards to QT prolongation has been limited to select populations. In our case, we demonstrate severe QT prolongation associated with Glycopyrronium bromide, emphasizing the need for further studies in a real-world 
Table 1 Summary Table of the glycopyrronium QT ${ }_{\mathrm{CF}}$ effects in the GLOW 1-6 trials (the GB in COPD airWays studies)[4-9]

\begin{tabular}{|c|c|c|c|}
\hline Aim of study; study size (N) & Patient population & $\begin{array}{l}\text { Study intervention } \\
\text { Study comparator }\end{array}$ & QT prolongation \\
\hline $\begin{array}{l}\text { GLOW-1 } \\
\text { Aim } \\
\text { Efficacy, safety and toler- } \\
\text { ability of GB in moderate/ } \\
\text { severe COPD } \\
\text { Study type } \\
\text { Randomized controlled trial } \\
\text { double blind } \\
\text { Size } \\
\mathrm{n}=822\end{array}$ & $\begin{array}{l}\text { Inclusion criteria } \\
\text { GOLD criteria-moderate to severe } \geq 40 \text { years of } \\
\text { age } \\
\text { Smoking history of } \geq 10 \text { pack-years } \\
\text { Exclusion criteriaPost-bronchodilator } \mathrm{FEV}_{1} \text { of }<80 \\
\text { and } \geq 30 \% \text { of predicted } \mathrm{FEV}_{1} / \mathrm{FVC} \text { ratio of }<0.70 \\
\text { Lower respiratory tract infection (RTI) within } \\
6 \text { weeks; concomitant pulmonary disease history } \\
\text { of asthma or lung cancer } \\
\text { Long QT syndrome: QTc }>450 \text { ms (males) or }>470 \\
\text { (females) } \\
\text { Symptomatic prostatic hyperplasia } \\
\text { Bladder-neck obstruction } \\
\text { Moderate/severe renal impairment } \\
\text { Urinary retention } \\
\text { Narrow-angle glaucoma } \\
\text { History of alpha- } 1 \text { antitrypsin }\end{array}$ & $\begin{array}{l}\text { Intervention } \\
\mathrm{GB} n=552 \text {, completed } 26 \text { week } \\
\text { trial } \mathrm{n}=450 \\
\text { Comparator } \\
\text { Placebo } \mathrm{n}=270 \text {, completed } \\
26 \text { week trial } \mathrm{n}=212\end{array}$ & $\begin{array}{l}\text { QTCF }>500 \mathrm{~ms} \\
\text { GB: } n=0(0 \%) \\
\text { Placebo: } n=0(0 \%) \\
\text { Increase of } 30-60 \mathrm{~ms} \\
\text { GB: } n=59(10.7 \%) \\
\text { Placebo } n=21(7.9 \%) \\
\text { Increase of }>60 \mathrm{~ms} \\
\text { GB: } n=6(1.1 \%) \\
\text { Placebo: } n=1(0.4 \%)\end{array}$ \\
\hline $\begin{array}{l}\text { GLOW-2 } \\
\text { Aim } \\
\text { Efficacy, safety and toler- } \\
\text { ability of GB in moderate/ } \\
\text { severe COPD vs placebo vs } \\
\text { tiotropium } \\
\text { Study type } \\
\text { Randomized controlled trial } \\
\text { (double blind) } \\
\text { Size } \\
\mathrm{n}=1066\end{array}$ & $\begin{array}{l}\text { Inclusion criteria } \\
\text { Males and females } \geq 40 \text { years of age } \\
\text { Smoking history of } \geq 10 \text { pack-years } \\
\text { GOLD moderate-to-severe COPD } \\
\text { Post-bronchodilator FEV1 } \geq 30 \text { and }<80 \% \text { of the } \\
\text { predicted } \\
\text { Post-broncho-dilator FEV1/FVC }<0.70 \\
\text { Exclusion criteria } \\
\text { Lower RTI } 6 \text { weeks prior } \\
\text { Concomitant pulmonary disease } \\
\text { Pulmonary tuberculosis } \\
\text { Bronchiectasis } \\
\text { History of asthma } \\
\text { Malignancy of any system } \\
\text { Long QT syndrome or QTc }>450 \text { ms (males) or }>470 \\
\text { (females) } \\
\text { Symptomatic prostatic hyperplasia } \\
\text { Bladder-neck obstruction } \\
\text { Moderate/severe renal impairment } \\
\text { Urinary retention } \\
\text { Narrow-angle glaucoma } \\
\text { History of a } \text { antitrypsin deficiency }_{\text {Active in pulmonary rehabilitation }} \\
\text { Contraindications for tiotropium or ipratropium or } \\
\text { history of adverse reactions to inhaled anticho- } \\
\text { linergics }\end{array}$ & $\begin{array}{l}\text { Intervention } \\
\mathrm{GB} n=529, \text { completed } 52 \text { week } \\
\text { trial } \mathrm{n}=411 \\
\text { Comparator } \\
\text { Placebo } \mathrm{n}=269 \text {, completed } \\
52 \text { week trial } \mathrm{n}=193 \\
\text { Tiotropium } \mathrm{n}=268 \text { completed } \\
52 \text { week trial } \mathrm{n}=206\end{array}$ & $\begin{array}{l}\text { QTCF }>500 \text { ms } \\
\text { GB: } n=2(0.4 \%) \\
\text { Placebo: } n=2(0.7 \%) \\
\text { Tiotropium: } n=0(0 \%) \\
\text { Increase of } 30-60 \text { ms: } \\
\text { GB: } n=83(15.8 \%) \\
\text { Placebo: } n=39(14.6 \%) \\
\text { Tiotropium: } n=43(16.2 \%) \\
\text { Increase of }>60 \mathrm{~ms} \\
\text { GB: } n=1(0.2 \%) \\
\text { Placebo: } n=1(0.4 \%) \\
\text { Tiotropium: } n=0(0 \%)\end{array}$ \\
\hline \multirow[t]{5}{*}{$\begin{array}{l}\text { GLOW-3 } \\
\text { Aim } \\
\text { Exercise tolerance with once } \\
\text { daily GB } \\
\text { Study type } \\
\text { Randomized Controlled Trial } \\
\text { (Double blind) } \\
\text { Size } \\
n=108\end{array}$} & $\begin{array}{l}\text { Inclusion criteria } \\
\text { GOLD moderate to severe COPD } \\
\text { Aged } \geq 40 \text { years } \\
\text { Smoking history } \geq 10 \text { pack-years } \\
\text { Post-bronchodilator } \mathrm{FEV}_{1}<80 \% \\
\geq 40 \% \text { of predicted normal } \\
\text { Post-bronchodilator } \mathrm{FEV}_{1} / \mathrm{FVC} \text { of }<70 \% \text {. } \\
\text { Exclusion criteria } \\
\text { Lower RTI prior } 6 \text { weeks } \\
\text { Oxygen for chronic hypoxemia } \\
\text { Concomitant pulmonary disease }\end{array}$ & $\begin{array}{l}\text { Intervention } \\
\mathrm{GB} \mathrm{n}=55 \\
\text { Comparator } \\
\text { Placebo } \mathrm{n}=53\end{array}$ & QTcF一not measured \\
\hline & Pulmonary tuberculosis & & \\
\hline & Bronchiectasis & & \\
\hline & History of asthma & & \\
\hline & Malignancy of any system & & \\
\hline
\end{tabular}


Table 1 continued

\section{Aim of study; study size (N) Patient population}

Long QT syndrome QTC >450 ms for males

or $>470$ ms for females,

Symptomatic prostatic hyperplasia

Bladder-neck obstruction

Moderate/severe renal impairment

Urinary retention

Narrow-angle glaucoma

Alpha-1 anti- trypsin deficiency

Adverse reactions to inhaled anticholinergic agents,

long- and short-acting alpha-agonists or

Sympathomimetic amines

Active pulmonary rehabilitation

\section{GLOW-4}

Aim

Efficacy, safety and tolerability of GB in moderate/ severe COPD vs tiotropium in the Japanese Population Study type

Randomized controlled tria (Double blind)

Size

$n=163$

\section{Inclusion criteria}

GOLD moderate-to-severe COPD

Males and females $\geq 40$ years of age

Smoking history of $\geq 10$ pack-years GOLD moderateto-severe COPD

Post-bronchodilator FEV $1 \geq 30$ and

$<80 \%$ of the predicted Post-broncho-dilator FEV1/

FVC $<0.70$

Exclusion criteria

Lower RTI prior 6 weeks

Oxygen for chronic hypoxemia

\section{GLOW-5}

Aim

Efficacy, safety and toler-

ability of GB in moderate/ severe COPD vs once daily tiotropium

Study type

Randomized controlled trial (double blind) Size

$n=657$
Concomitant pulmonary disease

Pulmonary tuberculosis

Bronchiectasis

History of asthma

Malignancy of any system

Long QT syndrome QTC >450 ms for males

or $>470$ ms for females,

Symptomatic prostatic hyperplasia

Bladder-neck obstruction

Moderate/severe renal impairment

Urinary retention

Narrow-angle glaucoma

Alpha-1 anti- trypsin deficiency

Adverse reactions to inhaled anticholinergic

agents, long- and short-acting alpha-agonists or sympathomimetic amines

Active pulmonary rehabilitation

Inclusion criteria

GOLD moderate-to-severe COPD

Males and females $\geq 40$ yrs of age

Smoking history of $\geq 10$ pack-yrs

GOLD moderate-to-severe COPD

Post-bronchodilator FEV $1 \geq 30 \%$ and $<80 \%$ of the predicted Post-broncho-dilator FEV1/FVC $<0.70$

Exclusion criteria

Lower RTI prior 6 weeks

Oxygen for chronic hypoxemia

Concomitant pulmonary disease

Pulmonary tuberculosis

Bronchiectasis

History of asthma

Malignancy of any system
Intervention QTCF-not measured

$\mathrm{GB} n=123$

Comparator

Placebo $n=40$

Intervention $\quad$ QTCF $>480 \mathrm{~ms}$

$\mathrm{GB} n=327$, completed 12 week GB: $n=2(0.64) \%$

trial $n=314 \quad$ Tiotropium: $n=0(0 \%)$

Comparator

Tiotropium $n=320$ completed $\quad G B: n=11(3.4 \%)$

12 week trial $n=316$
Tiotropium: $n=10$ (3\%) 
Table 1 continued

\begin{tabular}{|c|c|c|c|}
\hline Aim of study; study size (N) & Patient population & $\begin{array}{l}\text { Study intervention } \\
\text { Study comparator }\end{array}$ & QT prolongation \\
\hline $\begin{array}{l}\text { GLOW-6 } \\
\text { Aim } \\
\text { Efficacy, safety and tolerabil- } \\
\text { ity of GB and indacaterol vs } \\
\text { indacaterol alone in moder- } \\
\text { ate/severe COPD } \\
\text { Study type } \\
\text { Randomized controlled trial } \\
\text { (double blind) } \\
\text { Size } \\
n=449\end{array}$ & 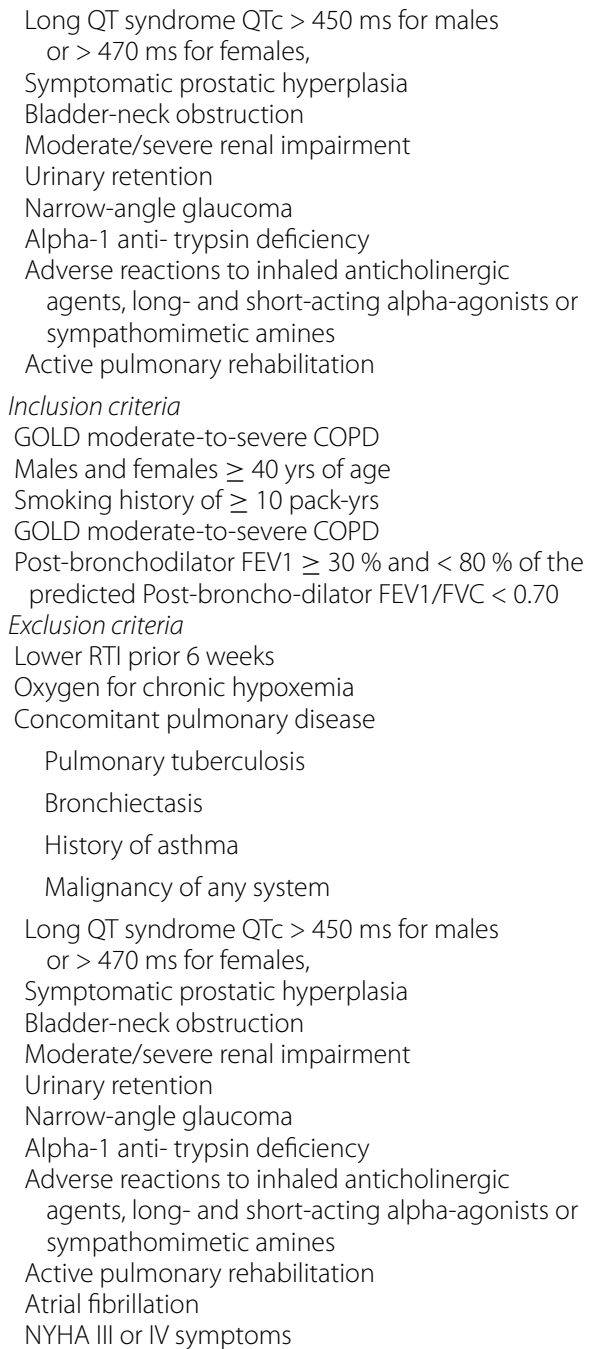 & $\begin{array}{l}\text { Intervention } \\
\mathrm{GB}+\text { Indacaterol } \mathrm{n}=226 \\
\text { Completed } 12 \text { week trial } \mathrm{n}=212 \\
\text { Comparator } \\
\text { Indacaterol } \mathrm{n}=223 \text { completed } \\
12 \text { week trial } \mathrm{n}=210\end{array}$ & $\begin{array}{l}\text { QTCF >500 ms: } \\
\text { GB + Ind: } n=0(0 \%) \\
\text { Ind: } n=0(0 \%) \\
\text { QTCF increase } 30-60 \mathrm{~ms}: \\
\text { GB + Ind: } \mathrm{n}=14(6.5 \%) \\
\text { Ind: } n=9(4.2 \%)\end{array}$ \\
\hline
\end{tabular}

$F E V_{1}$ forced expiratory volume in 1 second, FVC forced vital capacity, RTI respiratory tract infection

setting to identify high-risk patients that may benefit from ECG surveillance.

\section{Abbreviations}

COPD: chronic obstructive pulmonary disease; ED: Emergency Department; ECG: electrocardiogram; LAMA: long acting muscarinic antagonists; GB: glycopyrronium bromide; CBC: complete blood count; QTCF: corrected QT interval using Fridericia; QTcB: corrected QT interval using Bazett's formula; LQTS: Iong QT syndrome; TdP: torsades de pointes; GLOW: gLycopyrronium bromide in COPD airways.

\section{Authors' contributions}

All authors (MHC, NSA, RS, DP, RKS) were directly involved in care of the patient. MHC, NSA and RKS contributed to writing of the manuscript and all authors reviewed the manuscript (MHC, NSA, RS, DP, RKS). All authors read and approved the final manuscript.

\section{Author details}

${ }^{1}$ Division of Cardiology, Libin Cardiovascular Institute, University of Calgary, Calgary, AB, Canada. ${ }^{2}$ Division of Cardiology, University of Alberta, Edmonton, $A B$, Canada. ${ }^{3}$ Department of Internal Medicine, Faculty of Medicine, University of Alberta, Edmonton, AB, Canada. ${ }^{4}$ Department of Pharmacy, Mazankowski Alberta Heart Institute, University of Alberta, Edmonton, AB, Canada.

\section{Acknowledgements}

None.

Notification of prior presentation

This case has not been previously presented.

Availability of data and materials

All available is included in the manuscript.

\section{Competing interests}

The authors declare that they have no competing interests. 


\section{Consent to publish}

Written informed consent was obtained from the patient for publication of this case report and accompanying electrocardiograms.

\section{Ethical approval and consent to participate}

Not applicable.

\section{Funding}

The authors report no funding sources for this case report.

Received: 27 November 2015 Accepted: 31 May 2016

Published online: 14 June 2016

\section{References}

1. Rycroft CE, Heyes A, Lanza L, Becker K. Epidemiology of chronic obstructive pulmonary disease: a literature review. Int J Chron Obstr Pulm Dis. 2012;7:457-94.

2. Prakash A, Babu KS, Morjaria JB. Profile of inhaled glycopyrronium bromide as monotherapy and in fixed-dose combination with indacaterol maleate for the treatment of COPD. Int J Chron Obstruct Pulmon Dis. 2015;10:111-23.

3. Criner GJ, Bourbeau J, Diekemper RL, Ouellette DR, Goodridge D, Hernandez P, Curren K, Balter MS, Bhutani M, Camp PG et al. Prevention of acute exacerbations of chronic obstructive pulmonary disease: american college of chest physicians and canadian thoracic society guideline. Chest. 2015;147(4):894-942.

4. D'Urzo A, Ferguson GT, van Noord JA, Hirata K, Martin C, Horton R, Lu Y, Banerji D, Overend T. Efficacy and safety of once-daily NVA237 in patients with moderate-to-severe COPD: the GLOW1 trial. Respir Res. 2011;12(1):156

5. Kerwin E, Hébert J, Gallagher N, Martin C, Overend T, Alagappan VKT, LuY, Banerji D. Efficacy and safety of NVA237 versus placebo and tiotropium in patients with COPD: the GLOW2 study. Eur Respir J. 2012:40(5):1106-14.

6. Beeh KM, Singh D, Di Scala L, Drollmann A. Once-daily NVA237 improves exercise tolerance from the first dose in patients with COPD: the GLOW3 trial. Int J Chron Obstruct Pulmon Dis. 2012;7:503-13.

7. Chapman KR, Beeh K-M, Beier J, Bateman ED, D'Urzo A, Nutbrown R, Henley $\mathrm{M}$, Chen $\mathrm{H}$, Overend T, D'Andrea P. A blinded evaluation of the efficacy and safety of glycopyrronium, a once-daily long-acting muscarinic antagonist, versus tiotropium, in patients with COPD: the GLOW5 study. BMC Pulm Med. 2014;14:4.
8. Vincken W, Aumann J, Chen H, Henley M, McBryan D, Goyal P. Efficacy and safety of coadministration of once-daily indacaterol and glycopyrronium versus indacaterol alone in COPD patients: the GLOW6 study. Int J Chron Obstruct Pulmon Dis. 2014;9:215-28.

9. Sekiya M, Kawayama T, Fukuchi Y, Takahashi Y, Kaiso T, Ikeda K, Overend T, Banerji D. Safety and efficacy of NVA237 once daily in Japanese patients: the GLOW4 trial. Eur Respir J. 2012:40(Suppl 56):P2103.

10. Drollmann A, Sechaud R, Pal P, Hara H, Uziel-Fusi S, Winkle P. Glycopyrronium does not affect QT interval in healthy subjects: a randomized, three-period, cross-over, placebo- and positive-controlled study. Int J Clin Pharmacol Ther. 2014;52(9):739-45.

11. van Noord C, Eijgelsheim M, Stricker BHC. Drug- and non-drug-associated QT interval prolongation. Br J Clin Pharmacol. 2010;70(1):16-23.

12. Recanatini M, Poluzzi E, Masetti M, Cavalli A, De Ponti F. QT prolongation through hERG K + channel blockade: current knowledge and strategies for the early prediction during drug development. Med Res Rev. 2005;25(2):133-66.

13. Isbister GK, Page CB. Drug induced QT prolongation: the measurement and assessment of the QT interval in clinical practice. Br J Clin Pharmacol. 2013:76(1):48-57.

14. Nachimuthu S, Assar MD, Schussler JM. Drug-induced QT interval prolongation: mechanisms and clinical management. Ther Adv Drug Saf. 2012;3(5):241-53.

15. Heel RC, Brogden RN, Speight TM, Avery GS. Tamoxifen: a review of its pharmacological properties and therapeutic use in the treatment of breast cancer. Drugs. 1978;16(1):1-24.

16. Slovacek L, Ansorgova V, Macingova Z, Haman L, Petera J. Tamoxifeninduced QT interval prolongation. J Clin Pharm Ther. 2008;33(4):453-5.

17. Crewe HK, Notley LM, Wunsch RM, Lennard MS, Gillam EM. Metabolism of tamoxifen by recombinant human cytochrome P450 enzymes: formation of the 4-hydroxy, 4'-hydroxy and N-desmethyl metabolites and isomerization of trans-4-hydroxytamoxifen. Drug Metab Dispos. 2002;30(8):869-74.

18. Rennard S, Fogarty C, Reisner C, Fernandez C, Fischer T, Golden M, Rose ES, Darken P, Tardie G, Orevillo C. Randomized study of the safety, pharmacokinetics, and bronchodilatory efficacy of a proprietary glycopyrronium metered-dose inhaler in study patients with chronic obstructive pulmonary disease. BMC Pulm Med. 2014;14:118

19. Review of Glycopyrronium Bromide (Seebri) fby the Ministry of Health And Labor. Evaluation and Licensing Division, Pharmaceutical and Food Safety Bureau Japan 2012, Novartis Pharmaceuticals.

20. Canada NP: Product Monograph: Seebri Inhaler. In: Novartis Pharmaceutical Canada Inc. Dorval, QC; 2014

\section{Submit your next manuscript to BioMed Central and we will help you at every step:}

- We accept pre-submission inquiries

- Our selector tool helps you to find the most relevant journal

- We provide round the clock customer support

- Convenient online submission

- Thorough peer review

- Inclusion in PubMed and all major indexing services

- Maximum visibility for your research

Submit your manuscript at www.biomedcentral.com/submit
Biomed Central 